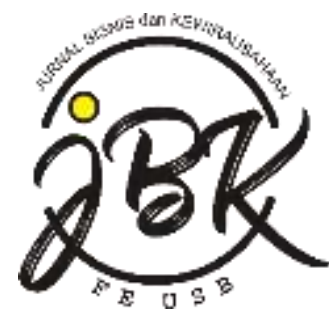

\title{
ALOKASI BELANJA MODAL KABUPATEN DAN KOTA DITINJAU DARI INDIKATOR KINERJA KEUANGAN DAERAH
}

\author{
Yunus Harjito 1 \\ Universitas Setia Budi Surakarta \\ (yunus.harjito@gmail.com) \\ Yunia Ike Lestari ${ }^{2}$ \\ IAIN Surakarta \\ (yikelestari@gmail.com) \\ Faiz Rahman Siddiq ${ }^{3}$ \\ Universitas Setia Budi Surakarta \\ (faizrahmansiddiq@gmail.com)
}

\begin{abstract}
This study aims to analyze the capital expenditure allocation of district and municipal as seen from local financial performance indicators. The data in this study is secondary data obtained from regional financial reports that have been audited by BPK RI. The variables that are expected to influence the allocation of capital expenditure in this study are the Regional Financial Independence, locally-generated revenue Effectiveness, Financial Efficiency, Debt Service Coverage Ratio, and Harmony of Expenditure. The sample in this study using districts and cities in East Java Province and selected based on purposive sampling method with five years observation period and using data analysis method used is multiple linear regression. The results showed that there are three influential variables: Regional Financial Independence, Local Financial Efficiency, and Harmony of Expenditure, while the other two variables namely locallygenerated revenue Effectiveness and Debt Service Coverage Ratio have no effect on capital expenditure allocation.
\end{abstract}

Keywords: Capital Expenditure Allocation, Regional Financial Ratio

\section{A. PENDAhuluan}

Berkurangnya campur tangan pemerintah pusat diharapkan dapat meningkatkan kemandirian pemerintah daerah dalam mengelola keuangan daerahnya. Hal ini lebih diperkuat dengan diberlakukannya Undang-Undang No. 22 tahun 1999 dan Undang-Undang No. 25 tahun 1999, yang kemudian diubah menjadi Undang-Undang No. 32 tahun 2004 dan
Undang-Undang No. 33 tahun 2004 tentang Pemerintah Daerah dan tentang Perimbangan Keuangan Antara Pusat dan Daerah, kewenangan pemerintah daerah menjadi lebih besar dalam mengelola sumber daya dan keuangan daerahnya sendiri. Kemampuan pemerintah daerah dalam mengelola keuangan daerahnya dapat diukur dengan analisis kinerja keuangan daerah. Kinerja keuangan dapat dilihat dari indikator 
yang digunakan sebagai acuan dalam menilai baik dan buruknya kinerja keuangan pemerintah daerah, indikator tersebut terdiri dari rasio-rasio keuangan. Rasio-rasio keuangan ini digunakan untuk: menilai kemandirian keuangan daerah dalam membiayai penyelengaraan otonomi daerah; mengukur efektivitas dan efisiensi dalam merealisasikan pendapatan daerah; mengukur sejauh mana aktivitas pemerintah daerah dalam membelanjakan pendapatan daerahnya; mengukur kontribusi masingmasing sumber pendapatan dalam pembentukan pendapatan daerah; melihat pertumbuhan atau perkembangan perolehan pendapatan dan pengeluaran yang dilakukan selama periode waktu tertentu (Halim, 2007).

Rasio-rasio yang lazim digunakan dalam analisis kinerja keuangan pemerintah daerah, merupakan perbandingan angkaangka dalam Laporan Realisasi Anggaran (LRA). Rasio-rasio yang sering digunakan dalam analisis kinerja keuangan pemerintah daerah adalah Rasio Kemandirian Keuangan Daerah, Rasio Ketergantungan Keuangan Daerah, Rasio Efektivitas Pendapatan Asli Daerah (PAD), Rasio Efisiensi Keuangan Daerah, Rasio Keserasian Belanja dan Rasio Pertumbuhan serta Debt Service Coverage Ratio (DSCR).

Gerungan dkk (2015) menyatakan bahwa rasio keuangan sebagai pengukur kinerja adalah Kemandirian Keuangan Daerah, Rasio Ketergantungan Keuangan Daerah, Rasio Efektivitas PAD, Rasio Efisiensi Keuangan Daerah, dan Rasio
Keserasian Belanja. Rahman dkk (2014) menyatakan bahwa kemampuan keuangan daerah diukur dari rasio kemandirian keuangan daeah, rasio derajat desentralisasi fiskal, rasio indeks kemampuan rutin, rasio keserasian, rasio pertumbuhan, sedangkan Karay (2012) menjelaskan bahwa kinerja keuangan diukur dengan indikator rasio kemandirian keuangan daerah, rasio efektivitas $P A D$, rasio efisiensi $P A D$, rasio efektivitas pajak daerah, dan rasio efisiensi pajak daerah.

Selain rasio-rasio yang digunakan dalam mengukur kinerja daerah, suatu pemerintah daerah juga harus dapat diukur melalui peningkatan melalui pembangunan daerhanya. Pendekatan yang diduga tepat untuk memberi gambaran tentang upaya pemerintah daerah dalam meningkatkan pembangunan daerahnya adalah melalui belanja modal. Untuk mendorong pembangunan daerah dan pertumbuhan ekonomi, pemerintah daerah perlu memberikan porsi yang lebih besar pada belanja modal dalam komposisi belanja daerah. Belanja modal yang disebut juga belanja pembangunan, mempunyai dampak positif dan signifikan terhadap pertumbuhan ekonomi. Menurut Adi (2006) pertumbuhan ekonomi yang selama ini terjadi sangat ditentukan oleh faktor belanja pembangunan daerah. Pembangunan infrastruktur dan fasilitas-fasilitas publik dapat meningkatkan kualitas pelayanan kepada masyarakat dan dapat menjadi daya tarik bagi para investor. Hal ini dapat memberikan peluang pada 
peningkatan pendapatan perkapita daerah dan dapat mendorong pertumbuhan ekonomi. Semakin besar alokasi belanja modal berarti pemerintah semakin serius dalam membangun daerah dan mensejahterakan masyarakat. Namun saat ini komposisi belanja masih didominasi oleh belanja operasional terutama belanja pegawai. Besarnya alokasi belanja modal itu sendiri ditentukan berdasarkan kinerja daerah tersebut.

Terdapat beberapa hasil penelitian terkait dengan belanja modal, diantaranya yaitu Gerungan dkk (2015) yang menyatakan bahwa kemandirian keuangan daerah, rasio efektivitas PAD, dan rasio keserasian belanja berpengaruh terhadap alokasi belanja modal, sedangkan rasio ketergantungan keuangan daerah, rasio efisiensi keuangan daerah, dan rasio keserasian belanja tidak berpengaruh terhadap alokasi belanja modal. Sularso dan Restianto (2011) menyatakan bahwa kinerja keuangan (derajat desentralisasi, ketergantungan keuangan, kemandirian keuangan, efektivitas PAD, dan derajat kontribusi PAD) mempengaruhi alokasi belanja modal, dan belanja modal mempengaruhi pertumbuhan ekonomi suatu daerah. Prihastuti dkk (2015) menyatakan bahwa rasio kemandirian keuangan, rasio efektivitas PAD, rasio aktivitas (rasio keserasian), rasio derajat desentralisasi, rasio ketergantungan keuangan berpengaruh terhadap alokasi belanja modal, sedangkan alokasi belanja modal tidak berpengaruh terhadap pertumbuhan ekonomi secara langsung.

Penelitian ini menggunakan variabel Debt Service Coverage Ratio (DSCR) sebagai salah satu indikator pengukur kinerja keuangan karena DSCR merupakan salah satu pengukur kemampuan daerah dalam mencari sumber pembiayaan untuk program pembangunannya (Sahade, 2011). Penelitian ini diharapkan dapat menjadi bahan pertimbangan bagi para pengambil kebijakan di jajaran pemerintah daerah dalam pengelolaan keuangan daerah, khususnya dalam hal peningkatan kinerja keuangan daerah dan dalam hal pengalokasian belanja modal. Selain itu juga dapat digunakan sebagai literatur bagi pihakpihak yang akan melakukan studi terkait atau penelitian selanjutnya.

\section{B. LANDASAN TEORI DAN PENGEMBANGAN HIPOTESIS}

\section{Agency Theory}

Hubungan keagenan sebagai suatu kontrak dimana satu orang atau lebih (prinsipal) meminta pihak lainnya (agen) untuk melaksanakan sejumlah pekerjaan atas nama prinsipal, yang melibatkan pendelegasian beberapa wewenang pembuatan keputusan kepada agen. Jika kedua pihak yang terlibat dalam kontrak tersebut berusaha untuk memaksimalkan utilitas mereka, maka ada kemungkinan bahwa agen tidak akan selalu bertindak untuk kepentingan terbaik prinsipal. Dengan tujuan memotivasi agen, maka prinsipal 
merancang kontrak sedemikan rupa sehingga mampu mengakomodasi kepentingan pihak-pihak yang terlibat dalam kontrak keagenan (Jensen and Meckling, 1976).

Teori agensi adalah hubungan atau kontrak antara prinsipal dan agen. Masalah keagenan (agency problems) muncul dalam dua bentuk, yaitu antara perusahaan (principal) dengan pihak manajemen (agent) dan antara pemegang saham dan pemegang obligasi. Tujuan normatif pengambilan keputusan keuangan yang menyatakan bahwa keputusan diambil untuk memaksimumkan kemakmuran pemilik perusahaan, hanya benar apabila pengambil keputusan keuangan (agent) memang mengambil keputusan dengan maksud untuk kepentingan para pemilik perusahaan (Mardiasmo, 2006:17).

Sulistyanto dkk. (2003) berpendapat bahwa manajer sebagai pengelola perusahaan merupakan satu-satunya pihak yang menguasai seluruh informasi yang diperlukan untuk menyusun laporan keuangan. Menurut penelitian Noviana dan Yuyetta (2011), ketika manajer mempunyai informasi yang lebih banyak dibandingkan pihak eksternal, maka akan ada asimetri informasi antara agen dan prinsipal. Agen atau manajer sebagai pihak internal lebih mengetahui keadaan perusahaan daripada pemilik. Manajer kemudian lebih memiliki kesempatan untuk melakukan disfunctional behavior, yaitu menggunakan informasi yang diketahuinya untuk memanipulasi pelaporan keuangan dalam usaha memaksimalkan kemakmurannya.

\section{Konsep Value For Money}

Haryanto dkk, (2007:8) menjelaskan bahwa value for money merupakan konsep pengelolaan organisasi sektor publik yang berdasarkan pada tiga elemen utama yaitu ekonomi, efisiensi, dan aktivitas. Ketiga hal tersebut merupakan elemen pokok value for money, namun beberapa pihak berpendapat bahwa tiga elemen saja belum cukup. Perlu ditambah dua elemen lagi yaitu keadilan (equity) dan pemerataan atau kesetaraan (equality). Lebih lanjut Haryanto dkk, (2007:9) menjelaskan bahwa keadilan mengacu pada adanya kesempatan sosial (social opportunity) yang sama untuk keadilan, perlu dilakukan distribusi secara merata (equality). Artinya penggunaan uang publik tidak hanya terkonsentrasi pada kelompok tertentu saja, melainkan dilakukan secara merata.

Value for money dapat tercapai apabila organisasi telah menggunakan biaya input paling kecil untuk mencapai output yang optimum dalam rangka mencapai tujuan organisasi. Kampanye implementasi konsep value for money pada organisasi sektor publik terutama Pemerintah Daerah gencar dilakukan seiring dengan meningkatnya tuntutan kinerja pada Pemerintah Daerah. Implementasi konsep value for money diyakini dapat memperbaiki akuntansi dan kinerja Pemerintah Daerah.

\section{Belanja Modal}


Belanja Modal adalah belanja yang dilakukan pemerintah yang menghasilkan aktiva tetap tertentu (Nordiawan, 2006:48). Berdasarkan Peraturan Menteri Dalam Negeri No. 59 Tahun 2007 pasal 53 (perubahan pertama dari Permendagri No. 13 Tahun 2006) menyatakan bahwa belanja modal digunakan untuk pengeluaran yang dilakukan dalam rangka pengadaan aset tetap berwujud yang mempunyai nilai manfaat lebih dari 12 bulan untuk digunakan dalam kegiatan pemerintahan. Nilai aset tetap berwujud yang dianggarkan dalam belanja modal sebesar harga beli/bangun aset ditambah seluruh belanja yang terkait dengan pengadaan/pembangunan asset sampai aset tersebut siap digunakan.

\section{Pengaruh Kemandirian Keuangan Daerah terhadap Alokasi Belanja Modal}

Kemandirian keuangan daerah (otonomi fiskal) menunjukkan kemampuan pemerintah daerah dalam membiayai sendiri kegiatan pemerintahan, pembangunan, dan pelayanan kepada masyarakat yang telah membayar pajak dan retribusi sebagai sumber pendapatan yang diperlukan daerah. Gerungan dkk (2015) dalam penelitiannnya menemukan hasil bahwa kemandirian, efektifitas, efisiensi, keserasian berpengaruh terhadap alokasi belanja modal, sedangkan ketergantungan, dan efektivitas belanja modal tidak berpengaruh terhadap alokasi belanja modal. Berdasarkan penjelasan di atas maka disusun hipotesis sebagai berikut:
$\mathbf{H}_{\mathbf{1}}$ : Kemandirian Keuangan Daerah berpengaruh terhadap Alokasi Belanja Modal.

\section{Pengaruh Efektivitas PAD terhadap Alokasi Belanja Modal}

Rasio efektivitas pendapatan dihitung dengan cara membandingkan realisasi pendapatan dengan target penerimaan pendapatan yang dianggarkan. Rasio efektivitas pendapatan menunjukan kemampuan pemerintah dalam memobilisasi penerimaan pendapatan sesuai dengan yang ditargetkan. Gerungan dkk (2015) dalam penelitiannnya menemukan hasil bahwa efektifitas PAD, berpengaruh terhadap alokasi belanja modal. Berdasarkan penjelasan di atas maka dinyatakan hipotesis sebagai berikut:

$\mathbf{H}_{\mathbf{2}}$ : Efektivitas PAD Berpengaruh Terhadap Alokasi Belanja Modal.

\section{Pengaruh Efisiensi Keuangan terhadap Alokasi Belanja Modal}

Untuk mengukur kinerja pemerintah daerah dalam memobolisasi penerimaan $P A D$, indikator rasio efektivitas $P A D$ saja belum cukup, sebab jika dilihat dari rasio efektivitasnya sudah baik tetapi bila ternyata biaya untuk mencapai target tersebut sangat besar, maka berarti pemungutan PAD tersebut tidak efisien. Oleh karena itu perlu pula dihitung rasio efisiensi PAD yang selanjutnya disebut Rasio ESPAD. Rasio ini dihitung dengan cara membandingkan biaya yang dikeluarkan pemerintah daerah untuk 
memperoleh PAD dengan realisasi penerimaan PAD. Untuk dapat menghitung rasio efisiensi $P A D$ ini diperlukan data tambahan yang tidak tersedia di Laporan Realisasi Anggaran, yaitu data tentang biaya pemungutan PAD. Gerungan dkk (2015) menyatakan bahwa efisiensi keuangan berpengaruh terhadap alokasi belanja modal. Oleh karena itu dinyatakan hipotesis sebagai berikut:

$\mathbf{H}_{\mathbf{3}}$ : Efisiensi Keuangan Berpengaruh Terhadap Alokasi Belanja Modal.

\section{Pengaruh Debt Service Coverage} Ratio (DSCR) terhadap Alokasi Belanja Modal

Analisis DSCR untuk melihat kemampuan Pemda dalam menggunakan alternatif sumber dana lain melalui pinjaman, hasil penilaian DSCR adalah perbandingan antara penjumlahan Pendapatan Asli Daerah, Bagian Daerah dari Pajak Bumi dan Bangunan, Bea Perolehan Hak atas Tanah dan Bangunan, Penerimaan Sumber Daya Alam, dan bagian daerah lainnya seperti: Pajak Penghasilan Perseorangan, serta Dana Alokasi Umum, setelah dikurangi Belanja Wajib, dengan penjumlahan Angsuran Pokok, Bunga, dan Biaya pinjaman lainnya yang jatuh tempo.

Hasil penelitian Sahade (2011) menjelaskan bahwa DSCR sebagai indiktor keuangan masing-masing daerah berbedabeda, hal ini menunjukkan bahwa kinerja keuangan tiap daerah berbeda. Perbedaan kinerja keuangan daerah akan mempengaruhi alokasi belanja modal yang diberikan oleh pemerintah, karena pemerintah juga harus memperhatikan pinjaman daerah yang belum dilunasi (outstanding) dan mengetahui peluang bagi pemerintah daerah untuk menarik pinjaman baru.

$\mathbf{H}_{4}$ : Debt Service Coverage Ratio Berpengaruh terhadap Alokasi Belanja Modal.

\section{Pengaruh Keserasian Belanja} terhadap Alokasi Belanja Modal

Keserasian ini menggambarkan bagaimana pemerintah daerah memprioritaskan alokasi dananya pada belanja rutin dan belanja pembangunan secara optimal. Semakin tinggi presentase dana yang dialokasikan untuk belanja rutin berarti presentase belanja pembangunan yang digunakan untuk menyediakan sarana prasarana ekonomi masyarakat cenderung semakin kecil. Gerungan dkk (2015) dalam penelitiannnya menemukan hasil bahwa keserasian berpengaruh terhadap alokasi belanja modal. Berdasarkan penjelasan diatas maka hipotesisnya adalah:

$\mathbf{H}_{5}$ : Keserasian Belanja Berpengaruh Terhadap Alokasi Belanja Modal.

\section{Model Penelitian}

Berdasarkan hipotesis yang telah diusulkan dalam penelitian ini maka dapat dibuat model penelitian sebagai berikut: 


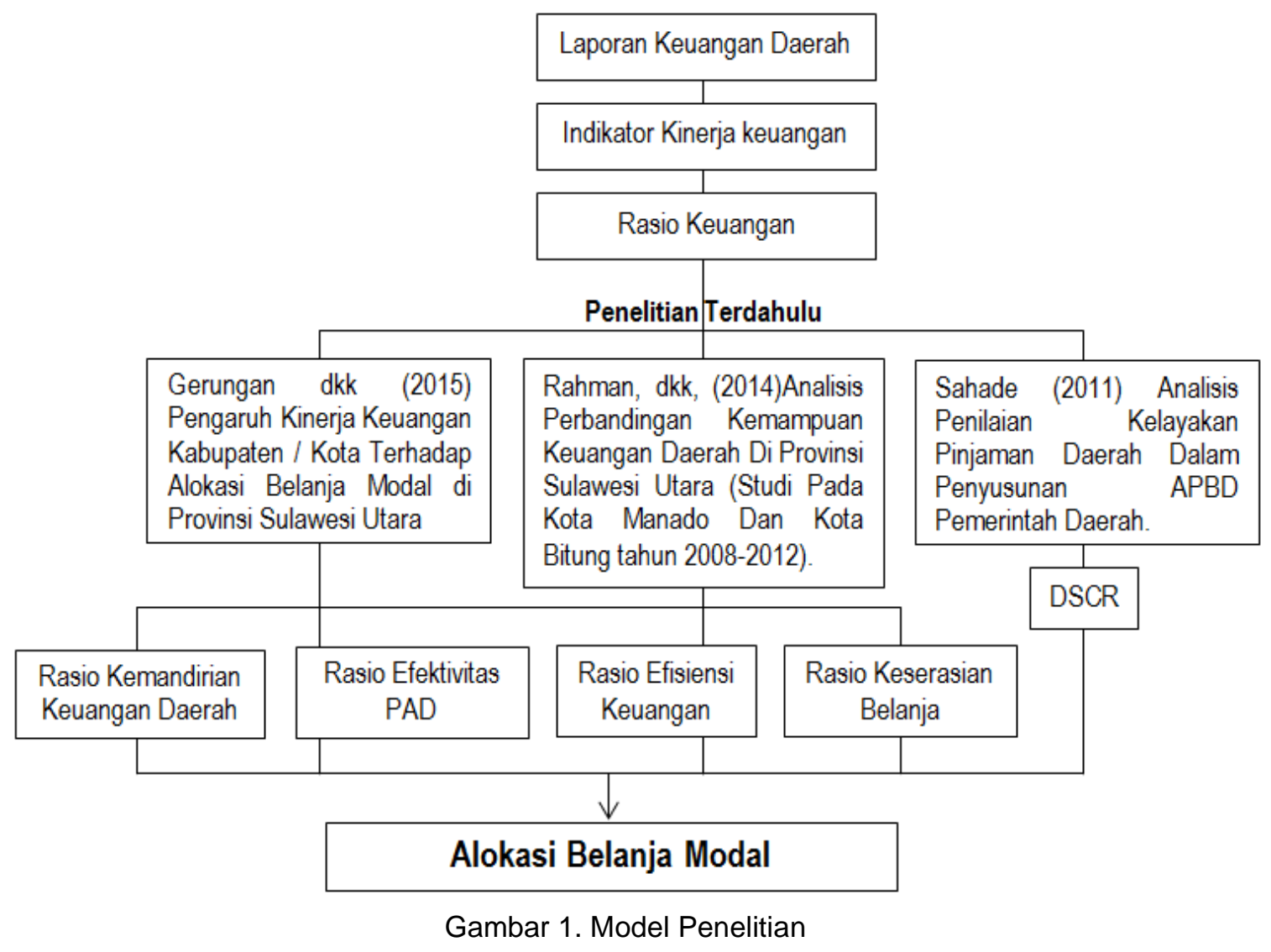

\section{METODE PENELITIAN}

1. Populasi, Sampel dan Teknik Penyampelan

Populasi yang menjadi objek dalam penelitian ini adalah seluruh Kota dan Kabupaten di Provinsi Jawa Timur. Sedangkan sampel yang digunakan dalam penelitian ini adalah kota atau kabupaten yang mengeluarkan laporan keuangan lengkap dan konsisten dari tahun 2015-2019 sesuai dengan variabel penelitian.
Pengambilan sampel yang akan diteliti dipilih berdasarkan metode purposive dengan judgement sampling. Beberapa kriteria yang melandasi pemilihan responden adalah:

a. Kota dan Kabupaten yang mengeluarkan laporan keuangan lengkap sesuai dengan variabel penelitian.

b. Kota dan Kabupaten yang mengeluarkan laporan keuangan konsisten dari tahun 2015-2019.

\section{Definisi Operasional Variabel}




\begin{tabular}{|c|c|c|}
\hline Variebel & Definisi & Pengukuran \\
\hline $\begin{array}{c}\text { Alokasi } \\
\text { Belanja } \\
\text { Modal (ABM) }\end{array}$ & $\begin{array}{l}\text { Adalah alokasi } \\
\text { pengeluaran anggaran } \\
\text { untuk perolehan aset } \\
\text { tetap dan aset lainnya } \\
\text { yang memberi manfaat } \\
\text { lebih dari satu periode } \\
\text { akuntansi. }\end{array}$ & $A B M=\frac{\text { Belanja Modal APBD }}{\text { Total Belanja Dalam APBD }} \times 100 \%$ \\
\hline $\begin{array}{l}\text { Kemandirian } \\
\text { Keuangan } \\
\text { Daerah } \\
\text { (KKD) }\end{array}$ & $\begin{array}{l}\text { Merupakan } \\
\text { kemampuan } \\
\text { pemerintah daerah } \\
\text { dalam membiayai } \\
\text { sendiri kegiatan } \\
\text { pemerintahan, } \\
\text { pembangunan, dan } \\
\text { pelayanan kepada } \\
\text { masyarakat yang telah } \\
\text { membayar pajak dan } \\
\text { retribusi sebagai } \\
\text { sumber pendapatan } \\
\text { yang diperlukan } \\
\text { daerah }\end{array}$ & $\frac{\text { Pendapatan Asli Daerah }}{(\text { Transfer Pusat }+ \text { Profinsi })+\text { Pinjaman }} \times 100 \%$ \\
\hline $\begin{array}{c}\text { Efektifitas } \\
\text { PAD }\end{array}$ & $\begin{array}{l}\text { kemampuan } \\
\text { pemerintah daerah } \\
\text { dalam merealisasikan } \\
\text { Pendapatan Asli } \\
\text { Daerah yang } \\
\text { direncanakan } \\
\text { dibandingkan dengan } \\
\text { target yang ditetapkan } \\
\text { berdasarkan potensi } \\
\text { riil daerah }\end{array}$ & $\frac{\text { Realisasi Penerimaan } P A D}{\text { Target penerimaan PAD berdasarkan potensi Riil }} X 100 \%$ \\
\hline $\begin{array}{l}\text { Efisiensi } \\
\text { Keuangan }\end{array}$ & $\begin{array}{l}\text { dihitung dengan cara } \\
\text { membandingkan biaya } \\
\text { yang dikeluarkan } \\
\text { untuk memperoleh } \\
\text { pendapatan dengan } \\
\text { realisasi penerimaan } \\
\text { pendapatan }\end{array}$ & $\frac{\text { Realisasi Belanja }}{\text { Realisasi Pendapatan }} X 100 \%$ \\
\hline DSCR & $\begin{array}{l}\text { Merupakan rasio untuk } \\
\text { melihat kemampuan } \\
\text { pemda dalam } \\
\text { menggunakan } \\
\text { alternatif sumber dana } \\
\text { lain melalui pinjaman. }\end{array}$ & $\frac{(P A D+B D+D A U)-\mathrm{BW}}{\text { Total (Pokok Angsuran }+ \text { Bunga }+ \text { Biaya Pinjaman })} \times 100 \%$ \\
\hline $\begin{array}{c}\text { Keserasian } \\
\text { Belanja }\end{array}$ & $\begin{array}{l}\text { menggambarkan } \\
\text { bagaimana pemda } \\
\text { memprioritaskan } \\
\text { alokasi dananya pada } \\
\text { belanja aparatur dan } \\
\text { belanja pelayanan } \\
\text { publik secara optimal. }\end{array}$ & $\frac{\text { Belanja Pelayanan Publik }}{\text { Total Belanja Daerah }} \times 100 \%$ \\
\hline
\end{tabular}

Tabel 1. Divinisi Operasional dan Pengukuran Variabel

\section{Analisis Data}

Teknik analisis data dalam penelitian ini menggunakan analisis regresi linier berganda dengan menggunakan program SPSS versi 21 for Windows agar dapat diketahui apakah ada pengaruh yang

- Yunus Harjito, Yunia Ike Lestari, dan Faiz Rahman Siddiq Jurnal Bisnis dan Kewirausahaan | Universitas Setia Budi 
signifikan dari beberapa variabel independen sebagai berikut:

terhadap variabel dependen dengan model

\section{$A B M$

$$
=\quad a+\beta_{1} K K D+\beta_{2} E F E K P A D+\beta_{3} E F S K E U+\beta_{4} D S C R+\beta_{5} K S R S+\varepsilon
$$

Keterangan :

$\begin{array}{lll}\text { ABM } & = & \text { Alokasi Belanja Modal } \\ \alpha & = & \text { Koefisien konstanta } \\ \beta 1-5 & = & \text { Koefisien regresi variabel independen } \\ \text { KKD } & = & \text { Kemandirian Keuangan Daerah } \\ \text { EFEKPAD } & = & \text { Efektifitas PAD } \\ \text { EFSKEU } & = & \text { Efisiensi Keuangan } \\ \text { DSCR } & = & \text { Debt Service Coverage Ratio } \\ \text { KSRS } & = & \text { Keserasian Belanja } \\ \varepsilon & = & \text { error }\end{array}$

D. HASIL ANALISIS DAN PEMBAHASAN

Populasi dalam penelitian ini adalah kabupaten dan kota di propinsi Jawa timur.
Pengambilan sampel dalam penelitian ini menggunakan teknik purposive sampling dengan hasil sebagai berikut:

\begin{tabular}{clc}
\hline No. & \multicolumn{1}{c}{ Kriteria } & Jumlah \\
\hline \hline 1. & Seluruh kabupaten dan kota di provinsi jawa timur & 38 \\
2. & Kota dan kabupaten yang mengeluarkan laporan realisasi APBD tidak & $(12)$ \\
& $\begin{array}{l}\text { lengkap dari tahun 2015- 2019 } \\
\text { 3. }\end{array}$ & Kota dan kabupaten yang mengeluarkan laporan keuangan tidak konsisten dari \\
4. & Juhun 2015 & $(10)$ \\
5. & Tahun pengamatan & 16 \\
\hline & $\quad$ Ukuran Sampel (16 x 5) & 5 \\
\hline & Sumber: Data diolah
\end{tabular}

Tabel 2. Sampel Penelitian

Berdasarkan dari hasil uji normalitas menggunakan pengujian One-Sample Kolmogorov-Smirnov Test menunjukan bahwa nilai signifikan yaitu $0,403(>0,05)$ hal ini berarti bahwa data terdistribusi normal (Ghozali, 2012). Selain itu dari hasil uji asumsi klasik tidak terjadi adanya pelanggaran asumsi yaitu multikolineearitas, heteroskedastisitas, dan autokorelasi. Oleh karena itu pengujian selanjutnya dapat dilakukan dan menunjukkan hasil sebagai berikut: 


\begin{tabular}{ccc}
\hline \multirow{2}{*}{ Variabel } & \multicolumn{2}{c}{ Unstandarized Coefficients } \\
\cline { 2 - 3 } & B & Sig \\
\hline \hline (Constant) & 0,185 & 0,202 \\
KKD & 0,133 & 0,047 \\
EFEKPAD & 0,008 & 0,783 \\
EFSKEU & $-0,249$ & 0,000 \\
DSCRi & 1,738 & 0,296 \\
KSRS & 0,661 & 0,000 \\
\hline \multicolumn{2}{l}{ Sumber: Data diolah } \\
\multicolumn{2}{c}{ Tabel 3. Hasil Analisis Regresi Linier Berganda }
\end{tabular}

Berdasarkan pada tabel analisis diatas, sebagai berikut :

persamaan model regresi linear adalah

\section{$M S=0,185+0,133 K K D+0,008$ EFEKPAD $-0,249$ EFSKEU $+1,738 D S C R i+0,661 K S R S+\varepsilon$}

Hasil output juga menunjukan bahwa nilai koefisien determinasi (Adj. $R^{2}$ ) sebesar 0,435 .

Dari hasil uji ANOVA atau $\mathrm{F}$ test menghasilkan $F$ hitung sebesar 11,252 dengan probabilitas signifikansi 0,000 . Nilai probabilitas jauh lebih kecil dari 0,05, maka model regresi dapat digunakan untuk memprediksi Market Share. Selain itu hasil Uji Hipotesis Secara Parsial menunjukkan hasil sebagai berikut:

\begin{tabular}{ccccc}
\hline \multirow{2}{*}{ Variabel } & \multicolumn{2}{c}{ Uji Signifikansi Koefisien Regresi } & \multirow{2}{*}{ Keterangan } \\
\cline { 2 - 4 } & $\mathbf{B}$ & $\mathbf{t}$ & Sig. & \\
\hline \hline KKD & 0,133 & 2,021 & 0,047 & Signifikan \\
EFEKPAD & 0,008 & 0,274 & 0,783 & Tidak Sign. \\
EFSKEU & $-0,249$ & $-4,549$ & 0,000 & Signifikan \\
DSCRi & 1,738 & 1,052 & 0,296 & Tidak Sign \\
KSRS & 0,661 & 5,248 & 0,000 & Signifikan \\
\hline
\end{tabular}

Sumber: Data diolah

Tabel 5. Hasil Uji t

\section{Kemandirian Keuangan Daerah berpengaruh signifikan terhadap Alokasi Belanja Modal \\ Rasio kemandirian menggambarkan} kemampuan keuangan daerah dalam membiayai sendiri kegiatan pemerintahan, pembangunan dan pelayanan kepada masyarakat yang telah membayar pajak dan retribusi sebagai sumber pendapatan yang diperlukan daerah. Dalam mendanai kegiatan pemerintahan maka akan semakin banyak belanja modal yang dikeluarkan, apabila pemerintah sudah memiliki kemandirian yang tinggi, pemerintah daerah tersebut tergolong maju, untuk menunjang perekonomian agar tetap berkembang maka perlu adanya pembangunan infrastruktur. Pembangunan infrastruktur merupakan salah satu bentuk belanja modal. Hasil penelitian ini mendukung penelitian dari Gerungan dkk (2015) dan Sularso (2011). 
2. Efektivitas PAD Tidak Berpengaruh terhadap Alokasi Belanja Modal

Rasio efektivitas pendapatan asli daerah tidak berpengaruh terhadap alokasi belanja modal, hal ini bisa saja terjadi karena target pemerintah kabupaten dan kota provinsi Jawa Timur bukan dalam alokasi belanja modal melainkan alokasi belanja operasional, dalam bentuk peningkatan jaminan sosial. Hasil penelitian ini tidak sejalan dengan hasil penelitian Gerungan dkk (2015) dan Prihastuti dkk (2015).

3. Efisiensi Keuangan Berpengaruh Signifikan Terhadap Alokasi Belanja Modal

Semakin tinggi rasio efisiensi, pengeluaran daerah dalam hal ini belanja modal semakin menurun. Penggunaan keuangan daerah yang tidak efisien dengan angka rasio yang tinggi dapat disebabkan karena jumlah realisasi pengeluaran lebih besar daripada jumlah penerimaan itu sendiri, sehingga terjadi pemborosan untuk belanja daerah tetapi tidak digunakan secara maksimal untuk belanja modal. Hal tersebut dikarenakan lebih besarnya belanja pegawai di daerah dibandingkan belanja modal guna pengembangan dan pembangunan di daerah. Hasil penelitian ini mendukung penelitian Gerungan dkk (2015) dan Sularso (2011).

Debt Service Coverage Ratio Tidak
Berpengaruh Terhadap Alokasi
Belanja Modal.

\begin{abstract}
Sessuai dengan teori untuk menentukan besarnya rasio hutang yang dimiliki suatu daerah tidak mmerlukan belanja modal melainkan belanja langsung atau belanja pegawai, yang mana belanja pegawai tersebut merupakan belanja operasional, sehingga besarnya rasio DSCR tidak berpengaruh terhadap alokasi belanja modal. Hasil penelitian ini sejalan dengan penelitian Sahade (2011).
\end{abstract}

5. Keserasian Belanja Berpengaruh Signifikan Terhadap Alokasi Belanja Modal

Untuk mencari keserasian belanja harus memperbandingkan antara realisasi belanja modal dengan realisasi belanja total, disini terlihat jelas bahwa besar kecilnya rasio keserasian belanja mempengaruhi alokasi belanja modal. Hasil penelitian ini sejalan dengan hasil penelitian Gerungan dkk (2015) dan Sularso, (2011).

\section{E. KESIMPULAN, KETERBATASAN, DAN SARAN}

Analisis terhadap belanja modal merupakan pendekatan yang diduga tepat untuk memberi gambaran tentang upaya pemerintah daerah dalam meningkatkan pembangunan daerahnya. Selain itu penggunaan rasio-rasio dalam analisis juga dapat memberikan gambarang mengenai kinerja daerah. Penelitian ini menunjukkan bahwa Kemandirian Keuangan Daerah, Efisiensi Keuangan Daerah, dan Keserasian Belanja berpengaruh signifikan terhadap 
Alokasi Belanja Modal pada Kabupaten dan Kota Provinsi Jawa Timur Tahun 2015-2019. Namun variabel Efektifitas PAD dan Debt Service Coverage Ratio yang diduga dapat mempengaruhi Alokasi Belanja Modal menunjukkan hasil yang sebaliknya.

Nilai koefisien determinasi (Adj. $\mathrm{R}^{2}$ ) sebesar 0,435 atau $43,35 \%$, hal ini mengindikasikan bahwa masih ada sekitar $56,65 \%$ varians variabel diluar model yang belum dugunakan dalam penelitian ini. Oleh karena itu untuk penelitian selanjutnya diharapkan dapat menggali variabel-variabel lain yang diduga dapat mempengaruhi alokasi belanja modal.

\section{REFERENSI}

Adi, Priyo Hari. 2006. Hubungan Antara Pertumbuhan Ekonomi Daerah, Belanja Pembangunan dan Pendapatan Asli Daerah (Studi pada Kabupaten dan Kota Se Jawa-Bali). Simposium Akuntansi 9 Padang.

Direktorat Jendral Perimbangan Keuangan.

Anggaran Pendapatan dan Belanja Daerah.

http//:www.djpk.depkeu.go.id

Direktorat Jendral Perimbangan Keuangan. Laporan Realisasi Anggaran. http//:www.djpk.depkeu.go.id

Gerungan, Sylvia Febriani; David P.E.Saerang; Wiston Pontoh. 2015. Pengaruh Kinerja Keuangan Kabupaten/ Kota Terhadap Alokasi Belanja Modal Di Provinsi Sulawesi
Utara. Jurnal Riset Akuntansi dan Auditing.Vol.6.No.1.ISSN:20888899.

Ghozali. 2011. Aplikasi Analisis Multivariate dengan Program SPSS, Cetakan 4. Semarang: BP Universitas Diponegoro.

Halim, Abdul. 2007. Akuntansi Keuangan Daerah. Edisi 3. Salemba Empat. Jakarta.

Haryanto; Sahmuddin; Arifuddin. 2007. Akuntansi Sektor Publik. Badan Penerbit Universitas Diponegoro.

Indriantoro dan Supomo. 2002. Metodologi Penelitian Bisnis. Edisi Pertama. BPFE: Yogyakarta.

Jensen, C. Michael and Meckling H. William. 1976. Theory of the Firm: Managerial Behavior, Agency Costs and Ownership Structure. Journal of Financial Economics.

Karay, Jonathan Cosmus.2012. Analisis Perbandingan Kinerja Keuangan Pemerintah Kabupaten Jayapura Sebelum Dan Sesudah Otonomi Khusus. Jurnal DINAMIS. Vol 2, No.12 Desember 2012.pp:32-41.

Mamesah, D.J. 1995. Sistem Administrasi Keuangan Daerah. Jakarta: PT.Gramedia Pustaka Utama.

Mardiasmo. 2006. Perwujudan Transparansi dan Akuntabilitas Publik Melalui Akuntansi Sektor Publik: Suatu Sarana Good Governance. Jurnal 
Akuntansi Pemerintah, Vol. 2 No. 1, Hal. 1-17.

Nordiawan, Dedi.2006. Akuntansi Sektor Publik. Jakarta: Salemba Empat. Noviana, Sindi Retno; Yuyetta, Erna Nur Afri. 2011. Analisis Faktor-Faktor Yang Mempengaruhi Praktik Perataan Laba (Studi Empiris Pada Perusahaan Manufaktur yang Terdaftar di BEI Periode 2006-2010). Jurnal Akuntansi dan Auditing. Vo.8.No.1.November 201:1-94.

Prihastuti, Asepma Hygi; Taufeni Taufik; Restu Agusti.2015. Pengaruh Kinerja Keuangan terhadap Alokasi Belanja Modal dan Pertumbuhan Ekonomi di Kabupaten/Kota Riau. Jurnal SOROT. Vol.10.No.2.pp:143-154. Lembaga Penelitian dan Pengabdian kepada Masyarakat Universitas Riau.

Rahman, Nikmah Astuti; Amran Naukoko; Albert Londah.2014. Analisis Perbandingan Kemampuan Keuangan Daerah Di Provinsi Sulawesi Utara (Studi Pada Kota Manado Dan Kota Bitung Tahun 2008-2012). Jurnal IImiah Berkala Efisiensi. Vol.14.No.3.

Republik Indonesia. 2003. Undang-undang Republik Indonesia Nomor 17 Tahun 2003. Tentang Keuangan Negara. 2007. Peraturan Menteri Dalam Negeri Nomor 59 Tahun 2007 Tentang Perubahan Atas Peraturan
Menteri Dalam Negeri No. 13/2006

Tetang Pedoman Pengelolaan Keuangan Daerah.

$\begin{array}{lcrr} & 2000 . & \text { Peraturan } \\ \text { Pemerintah } & \text { Republik } & \text { Indonesia } \\ \text { Nomor 105 } & \text { Tahun } 2000 & \text { Tentang } \\ \text { Pengelolaan } & \text { dan }\end{array}$

Pertanggungjawaban Keuangan Daerah.

$\begin{array}{ccr} & 2005 . & \text { Peraturan } \\ \text { Pemerintah } & \text { Republik } & \text { Indonesia } \\ \text { Nomor } 58 & \text { Tahun } 2005 & \text { Tentang } \\ \text { Pengelolaan Keuangan Daerah. }\end{array}$

Pemerintah Republik Indonesia Nomor 71 Tahun 2010 Tentang Standar Akuntansi Pemerintahan. 2004. Undang-Undang Republik Indonesia Nomor 1 Tahun 2004 Tentang Perbendaharaan Negara. . 2004. Undang-Undang Republik Indonesia Nomor 32 Tahun 2004 Tentang Pemerintahan Daerah.

2004. Undang-Undang Republik Indonesia Nomor 33 Tahun 2004 Tentang Perimbangan Keuangan Antara Pemerintah Pusat dan Pemerintah Daerah.

Sahade. 2011. Analisis Penilaian Kelayakan Pinjaman Daerah Dalam Penyusunan APBD Pemerintah Daerah. Jurnal Ikhtiyar. Vol.9. No.3.September-Desember 2011. 
Sakaran,Uma. 2006. Metodologi Penelitian Untuk Bisnis. Edisi 4. Buku 1. Jakarta: Salemba Empat.

Sularso; Yanuar. E.Restianto. 2011.

Pengaruh Kinerja Keuangan

Terhadap Alokasi Belanja Modal Dan

Pertumbuhan Ekonomi

Kabupaten/Kota Di Jawa Tengah.

Media Riset Akuntansi. Vol 1.

No.2.ISSN:2088-2106.

Sulistyanto, H.Sri, dan Midiastuti, Pratana P., 2003, "Seasoned Equity Offerings: Benarkah Underperformance Pasca Penawaran", Simposium Surviving Strategies to Cope With the Future, Universitas Atma Jaya Yogyakarta, 13-14 September.

Utama, Suyana.2009. Analisis Kinerja Keuangan Daerah Pada Kabupaten/Kota di Provinsi Bali 2001-2006. Buletin Studi Ekonomi. Vol.14. No.2. Tahun 2009.ISSN: 1410-4628.

Widarjono, Agus. 2010. Analisis Statistika Multivariat Terapan. Edisi Pertama. Yogyakarta: UPP STIM YKPN 